\title{
Petrography and Mineralogy of Egyptian Alabaster in Wadi Mawathil Area, Eastern Desert, Egypt
}

\author{
Ahmed M El Mezayen ${ }^{1}$, Darweesh M. El-Kholy ${ }^{2, *}$, Mohamed W. Abd El-Moghny ${ }^{1}$, Hossam A. \\ Khamis $^{2}$, and Alaa T. Ahmed ${ }^{1,3, *}$ \\ ${ }^{l}$ Department of Geology, Faculty of Science, Al-Azhar University, Cairo, Egypt \\ ${ }^{2}$ Nuclear Material AuthorityCairo, Egypt \\ ${ }^{3}$ Beni-Suef Quarries Administration, Beni-Suef, Egypt
}

*Corresponding Author: Darweesh M. El-Kholy, Nuclear Material Authority Cairo, Egypt

Email: darweeshelkholy9@yahoo.com

\begin{abstract}
The study area is represented by Middle Eocene Nummulitic limestoneexhibiting karst features. It is quarried and commercially containing the rocks known "Egyptian Alabaster" and "Bucchino".The "Egyptian alabaster" is one of the most required stone types in Ancient Egyptian Pharaonic period.Wadi Mawathil alabaster shows a variety of structures as, veins, banding, and cavity filling. Banding is a predominately feature of the study area, it is the result of the physiochemical processes with time. Petrographically, these limestones show six microfacies types namely; Echinoidal bioclastic wackestone, Molluscan bioclastic packstone, Foraminiferal bioclasic packstone, Nummulitic bioclastic packstone, Foraminiferal packstone and Sandy molluscan grainstone. These facies indicate quite open marine and shallow subtidal depositional environment. X-ray diffraction analyses exhibit the mineralogical composition of the Middle Eocene limestone to be mainly of calcite. Scanning electron microscope study (SEM analysis) of the alabaster rocks shows that the major mineral component of the studied rock samples is calcite. The SEM analysis gave a prediction of the history of crystallization of the alabaster bands and also showed the difference between them; the shape of milky-white band is fine-grained, indicating that the calcium carbonate had been rapidly precipitated as calcite mineral when $\mathrm{CO}_{2}$ is given off, while the grain shape of the brownish-translucent band is coarse, this indicates a slow rate of crystallization.
\end{abstract}

Keywords: Alabaster, Petrograpgy, Mineralogy, Bucchino, Sannur Formation

\section{INTRODUCTION}

Wadi Mawathil area lies at the northern part of the Eastern Dessert of Egypt. The study area is located between Latitudes $28^{\circ} 30^{\circ}$ and $28^{\circ} 40^{\circ}$ North, and Longitudes $31^{\circ} 15^{\circ}$ and $31^{\circ} 25^{\circ}$ East(Fig. 1). It is accessible by the free eastern asphaltic road of Cairo - Assiut $36 \mathrm{~km}$ SE of Beni Suif. Stratigrafically, This area is composed mainly of carbonate rocks known by "Sannur Formation" of Middle Eocene age. These rocks are mainly fossiliferous limestone associated with patches of crystalline calcite (Egyptian Alabaster)exhibiting karst features. The area under investigation is quarried and commercially containing the rocks known "Alabaster" and "Bucchino" which are used for decoration and building purpose. The "Egyptian Alabaster" is one of the most required stone types in Ancient Egypt (Klemm and Klemm, 2001). The field observations revealed that these limestone were subjected to series of diagenetic processes as cementation, dissolutions and recrystallization.

Yahia (2010) studied the geomorphology and sedimentology of the upper tributaries of Wadi and Gabal Sannur south east Beni Suef, Egypt.Railsback (2002) carried out petrographical and geochemical studies of the speleothems of W. Sannur cavern of Egypt for the purpose of clarification the nature of recrystallized speleothems. Akkad and Naggar (1963) studied the geology of Wadi Sannur alabaster and the general geologic history of the Egyptian Alabaster deposits. Akkad and Naggar (1965) studied the petrography of Wadi Sannur Alabaster and the mode of formation of Egyptian Alabaster. The present study deals with geologic setting, petrography and mineralogy of alabaster in the area under study, for these aims. One stratigraphic section is measured, studied and 
sampled at Wadi Mawathil. The essential reason of selecting this area as a point of research is that; it is generally, the economic importance of alabaster and bucchino as, ornamental and building stone, especially "Egyptian Alabaster".

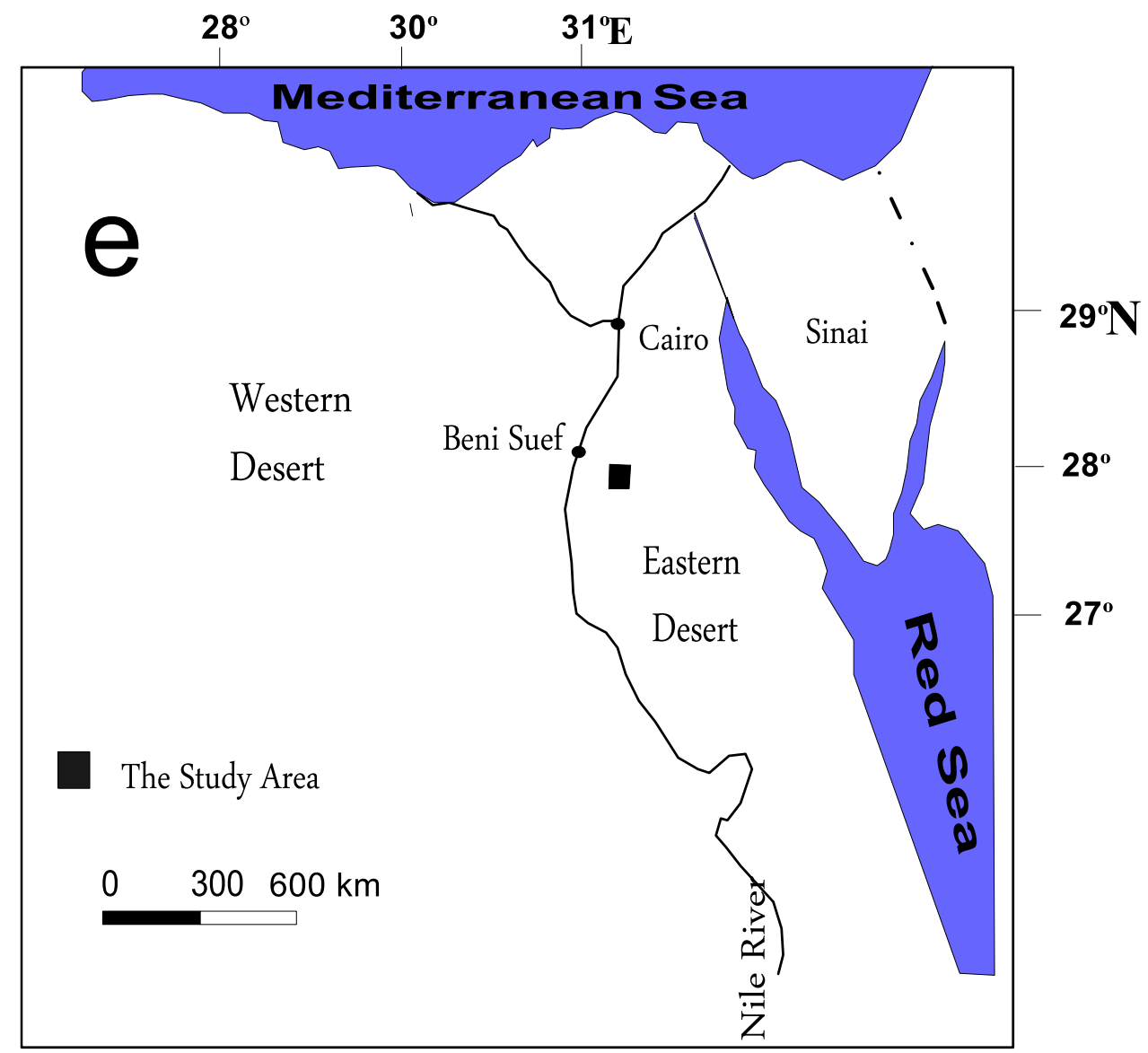

Fig1. Location map showing W. Mawathil area, western part of the north Eastern Desert

\section{GEOLOGIC SETTING}

Wadi Mawathil alabaster is located at the intersection of lat. $28^{\circ} 30^{\circ}$ and $28^{\circ} 40^{\circ}$ North, and Long. $31^{\circ}$ $15^{`}$ and $31^{\circ} 25^{\prime}$ East. Wadi Mawathil area is characterized by moderate to low topographic hills. Stratigraphically, the study area is represented by "Sannur Formation" (Boukhary and Abdelmalik, 1983) of Middle Eocene age. The Sannur Formation attains about 110 m thickness (Rifai, 2007).The exposed lithostratigraphic section in the area under investigation is mainly fossiliferous limestone associated with patches of crystalline calcite (Egyptian Alabaster) exhibiting karst features. This lithostrati graphic section is composed of alabaster at base, followed by nummulitic limestone (hard limestone known "bucchino" and chalky limestone) at top with a little Quaternary conglomerates. This rocks are associating with red soils (rich in iron oxides) which is known as "Terra Rosa".

The Egyptian Alabaster usually tenders some xenoliths of limestones up to $30 \mathrm{~cm}$ in diameters (Alamoudi and El-Taher, 2016).

Wadi Mawathil alabaster shows a variety of structures, as veins, banding, and cavity filling. Banding is a predominately feature of this area (Fig. 2a), it is the result of the physiochemical processes with time (Craig and Vaughan, 1981).The alabaster also appears as, cavernous shape (Fig. 2b).In the study area the alabaster rock occurs in the form of consecutive bands, it has successive brownish-honey color translucent and milky-white bands alternating with each other. Gradation of growth has been seen between the translucent and the white bands (Blasy, 2014). The thickness of brownish-honey color translucent bands commonly varies from 0.2 to $6.3 \mathrm{~cm}$, while in the milky-white bands varies from 0.1 to $5.8 \mathrm{~cm}$.

Generally, according to the previous studieson the study area and the field observations, the Egyptian Alabaster occurs within the Eocene limestone only as cavity and fissure fillings (Akaad and Naggar, 1963, 1964 a \& b, and Philip et. al., 1991, and Kelemm and Klemm, 1993). 

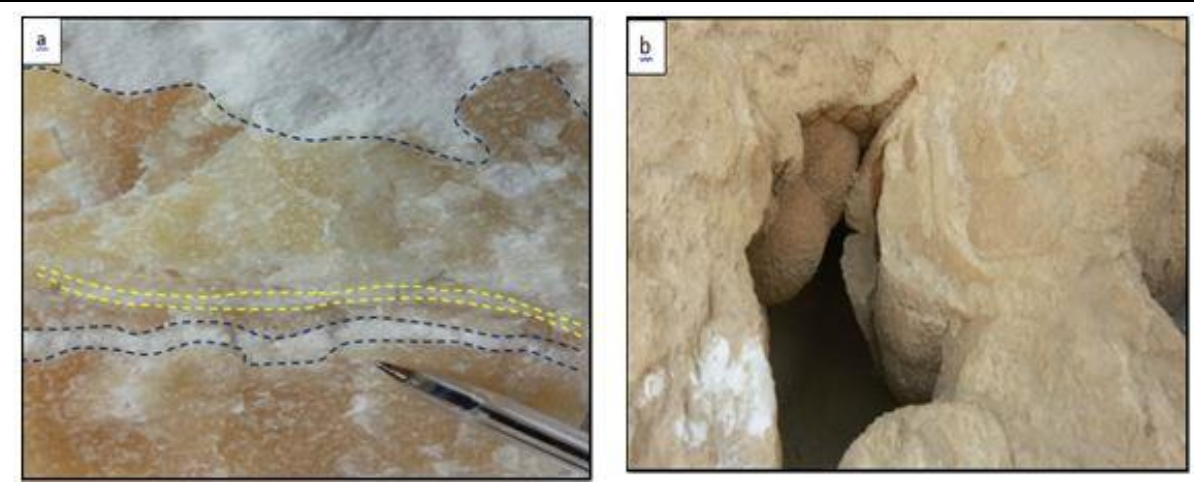

Fig2. Photograph showing; (a) successive alabaster bands, and (b) alabaster occurs as cavity filling

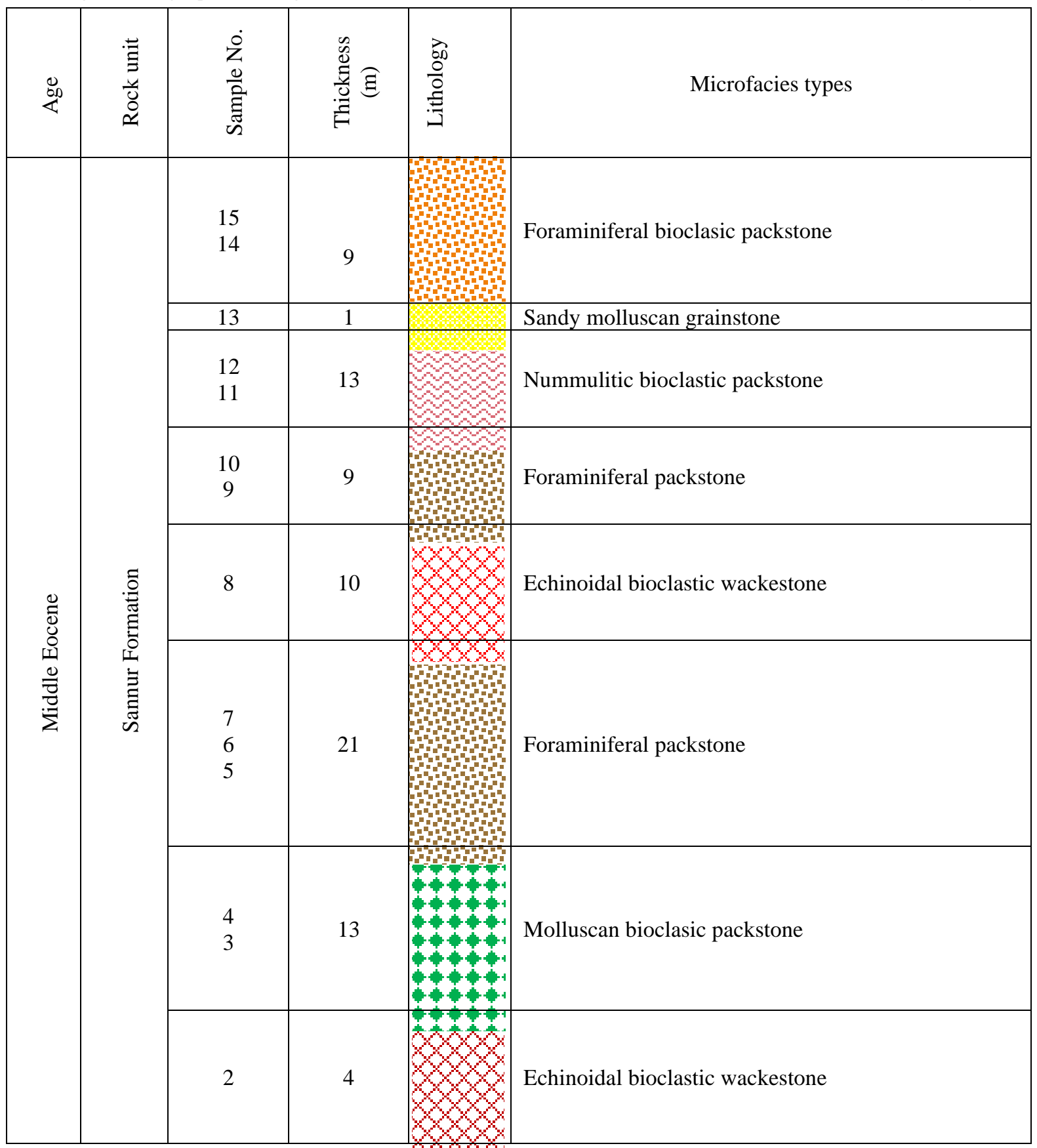

Fig3. Stratigraphic column of Sannur Formation showing microfacies types

\section{Petrography}

\subsection{Microfacies Associations}

Seventeen thin sections were prepared and microscopically examined to determine their mineral composition, textures and digenetic processes of the studied carbonate rocks. The microfacies types of 
the studied carbonate rocks are classified according to the schemes of Folk $(1959,1962$ and 1974) and Dunham (1962)that based upon their allochemical and/or the chemical components as well as their textural characteristics. The examination of different microfacies types was carried out to interpret the environmental conditions of these deposits. Six microfacies types are recognized in these carbonate rocks, represented by the following: Echinoidal bioclastic wackestone, Molluscan bioclastic packstone, Foraminiferal bioclastic packstone, Nummulitic bioclastic packstone, Foraminiferal packstone, Sandy molluscan grainstone. These microfacies are listed in (Fig.3).

\subsubsection{Echinoidal Bioclastic Wackestone}

This microfacies type is recordedin sample No. 2 in the lower part of the Sannur Formation at the studied stratigraphic section in W. Mawathil area. It is composed of yellowish white, hard, fossiliferous limestone. Petrographically, the allochems compose more than $20 \%$ of this microfacies and are represented by echinoidal fragments with their calcite overgrowth cement as diagenetic feature (Fig. 4a). Foraminiferal and pleceypod shell fragments forming $<5 \%$ of the rock. The foraminiferal tests are filled with sparite cement and their walls are completely micritized. The pleceypod fragments totally recrystallized into microcrystalline fibrous calcite. These allochems are embedded in cryptocrystalline calcite matrix.

Interpretation: The enrichment of micrite matrix and reliability of bioclastic diversity reveal the quit marine, shallow subtidal depositional environment.

\subsubsection{Molluscan Bioclasic Packstone}

This microfacies type is also detected in the lower part at the studied section. It is composed of brownish yellowish white, hard, fossiliferous limestone. Microscopically, the allochems of this microfacies form $>40 \%$ of the rock and are represented by ill-sorted,mollusca foraminifera, and echinoids fragments (Fig. 4b). Foraminiferal tests are either filled by micrite matrix or calcite cement. The majority of the pleceypod fragments are recrystallized into mosaic macrocrystalline calcite and occasionally fibrous calcite (Fig. 4c). Echinoidal fragments are characterized by calcite overgrowth cement. These bioclasticgrains are embedded in cryptocrystalline calcite matrix that occasionally recrystallized into microcrystalline cement (sparite) patches.

Interpretation: The enrichment of micrite matrix as well as high diversity bioclastic cement reflect the quite open marine, shallow subtidal depositional environment.

\subsubsection{Foraminiferal Bioclastic Packstone}

This microfacies type is recorded in the upper part of studied section. It is composed of yellowish white, greyish white, hard, massive, fossiliferous limestone. The allochems of this microfacies compose about $30-35 \%$ of the rock and are represented mainly by foraminifera (Fig.4d), echinoid, and ostracod shell fragments. The chamber of the foraminiferal and ostracod tests are filled by macrocrystalline calcite where their walls are micritized. Crystalline calcite of the isopodous type can be observed covering the outer surface of some bioclastic grains. These bioclastic grains are embedded in cryptocrystallinecalcite matrix. Dissolution as a diagenetic process is well developed in the subsurfaces forming vuggy type.

Interpretation: The bioclastic diversity including planktonic foraminifera, echinoid and ostracod as well as the micrite matrix reflect quiet shallow subtidal open marine environment.

\subsubsection{Nummulitic Bioclastic Packstone}

This microfacies type is observed in the upper part at the studied section. It is composed of milky white, semi hard, fossiliferous, chalky limestone. Microscopically, allochems of this microfacies which comprise up to $50 \%$ of this rock are represented by Nummulites, echinoids and bivalve shell fragments. Nummulite tests are completely recrystallized into mircocrystalline calcite (Fig. 4e). These allochems are embedded in spary calcite matrix. The matrix is dissolved and form channel porosity type.

Interpretation: The enrichment of larger foraminifera (Nummulites) and calcite matrix reflect open, shallow subtidal quiet marine environment.

\subsubsection{Framiniferal Packstone}

This microfacies type is recorded in the middle part at the studied section. It is composed of smoky white, hard, fossiliferous limestone.

Microscopically, allochems of this mircofacies forming 35-40\% of this rock and are represented by Nummulite shell fragments (Fig.4f). Nummulite tests are completely recrystallized into crystalline 
calcite. These allochems are embedded in cryptocrystalline calcite matrix that partially recrystallized into spary calcite.

Interpretation: The enrichment of larger foraminifera (Nummulites) and calcite matrix reflect open, shallow subtidal quiet marine environment.

\subsubsection{Sandy Molluscan Grainstone}

This microfacies type is recorded in the upper part of the studied section at W. Mawathil area. It consists of reddish brown, sandy, fossiliferous ferrugeneous, limestone. The allochems of this microfacies are represented by molluscan fragments and macrocrystalline, angular to subangular fine to coarse moderately sorted quartz grains (Fig. $4 \mathrm{~g}$ ). Molluscan fragments mainly are gastropod and filled by fine to very fine sand grains. Few $(<5 \%)$ glauconite pellets can be noted as rounded, homogeneous, pale green to yellowish green grains (Fig. 4h). These bioclastic and lithoclastic grains are embedded in macrocrystalline calcite cement. Iron oxide patches can be noted that may be due to the oxidation of iron-rich minerals.

Interpretation: The presence of gastropod and the enrichment of detrital influx and their textural characteristics reflect an intertidal depositional environment.
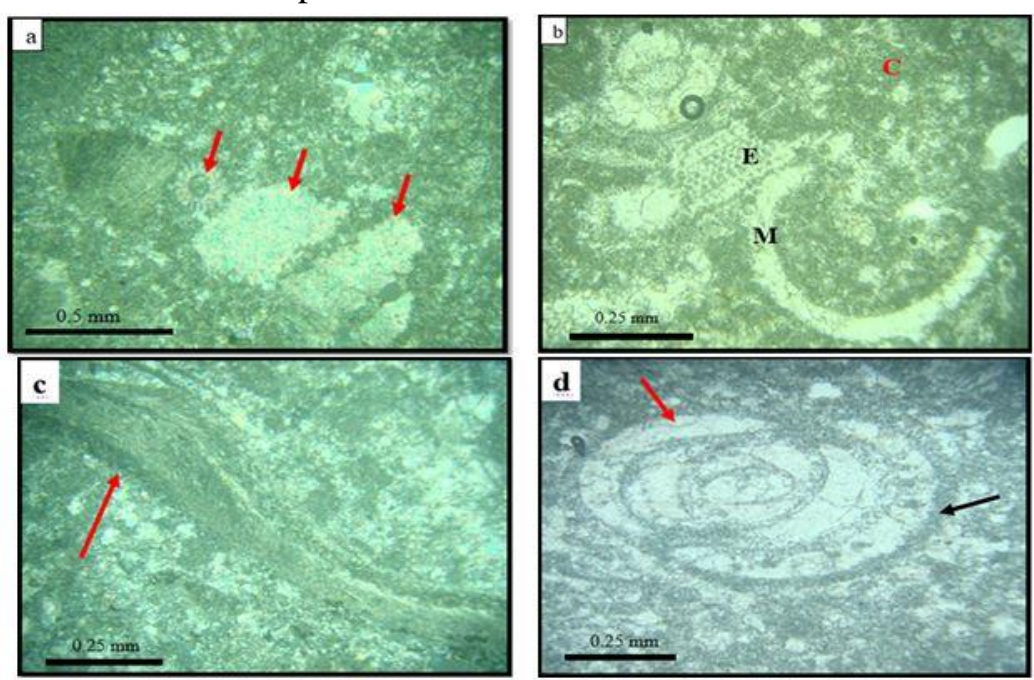

Fig4. Photomicrograph showing; (a) echinoidal fragments (arrows) with their calcite overgrowth cement, (b) mollusca " $M$ " and echinoids " $E$ " are embedded in cryptocrystalline calcite matrix "c", (c) pleceypod fragments (arrow) as recrystallized into mosaic microcrystalline calcite, (d) the chamber of the foraminiferal tests are filled by macrocrystalline calcite (red arrow) where their walls are micritized (black arrow), (e) allochems (black arrows) are embedded in cryptocrystalline calcite matrix that partially recrystallized into spary calcite patches (red arrow), (f) Molluscan fragments act as trap of different grains " $G$ ”, and ( $g$ ) Lithoclastic angular to subangular fine to coarse moderately and sorted quartz grains are embedded in macrocrystalline calcite cement, also the iron oxide patches (black arrow) and glauconitic pellets (red arrow) can be noted
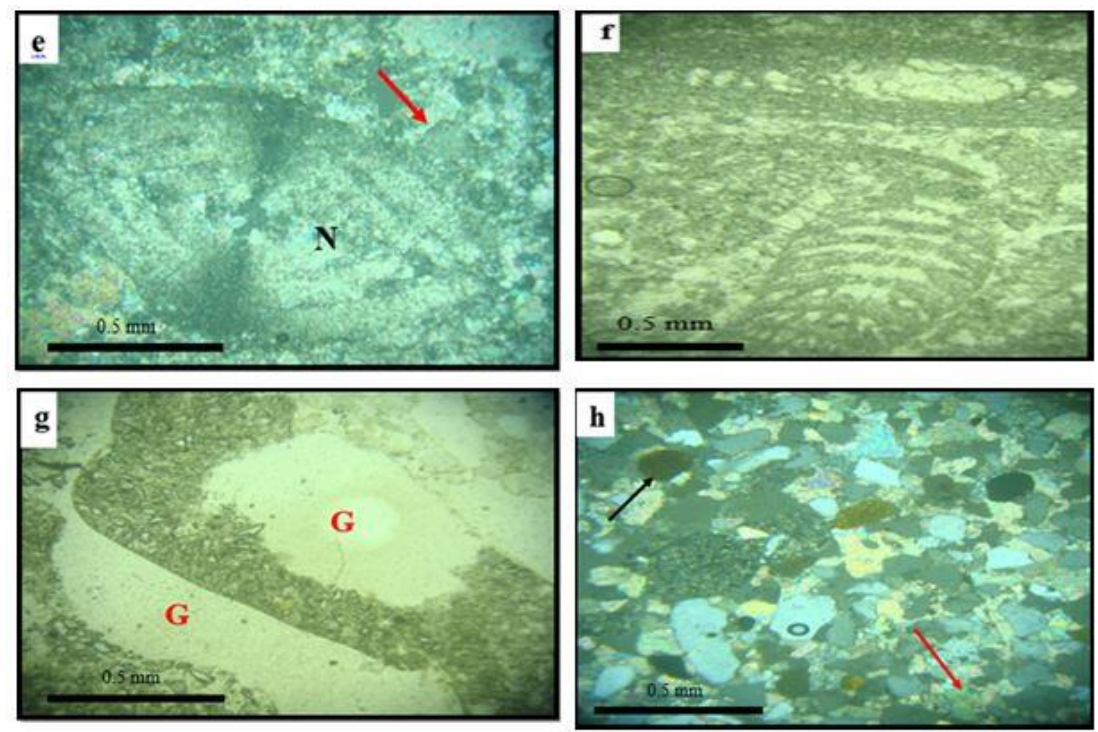

Fig4. Continue 


\subsection{Diagenetic Processes}

Diagenesisprocesses are very important in sedimentology. They refer to the reaction between one mineral and another or between minerals and fluids within sedimentary rocks after deposition. The interstitial fluids react with the surrounding carbonate sediments in various diagenetic environments to produce changes in mineralogy and porosity, which affect on texture and fabric of limestone (Gharieb, et al., 1998). The diagenesis of carbonaterocks involves several processes and occurs in near surface marine and meteoric environments, also affect a sediments porosity and permeability (Tucker, 2001).Generally, diagenesis refers to all processes affecting the sediments after deposition (El Hefnawi, et al., 2010).

The petrographical investigation of the studied carbonate rocks revealed that they are subjected to some processes such as neomorphism (recrystallization), cementation and dissolutions. These processes that act on these materials after deposition causing influence by physicochemical processes on the studied rocks.

\subsubsection{Cementation}

Cementation process is the major diagenetic process producing a hard limestone. It occurs by physicochemical and biochemical processes. The investigation of the thin sections in the study area shows that the cement materials of the studied rocks are calcium carbonate (calcite) in various forms as; microcrystalline calcite "microsparite", crystalline spary calcite and rarely cryptocrystalline calcite "micrite" (Fig. 5a). According to (Yehia, 2010) the source of cement in the studied area perhaps from the site of deposition (endogenic), or from outside the depositional basin (exogenic). Iron oxide content is detected in microfacies type and may refer to the alteration of iron-rich minerals.

\subsubsection{Neomorphism}

Neomorphism refers to replacement and recrystallization processes, and they are perhaps occurring in mineral composition. The term "Neomorphism" is used by Folk, (1965)to cover all transformations between one mineral and itself (recrystallization) or a polymorph (inversion) e.g. aragonite to calcite without chemical change (calcitization). The micrite in the most walls of bioclastics of the studied microfacies had transformed into microspar and/or sparry calcite as a "polymorph neomorphism" (Fig. 5a). Thin section studies of the rocks show that the fragments of bivalve shells are composed of crystalline calcite (Fig. 5b). Flügel, (2004) mentioned that the aragonitic shell fragmentsare influenced by dissolving to form complete or partial moldsthat may be subsequently filled with cement, or they may be transformed to low-Mg calciteduring recrystallization by the simultaneous volume per volume dissolution of aragonite and precipitation of calcite.

Calcite cements of the alabaster samples are characterized by radial fibrous (Fig. 6a). These cements are filling pores. These diagenetic calcite types show gradationof growth between the alabaster bands and recrystallized ones in cryptocrystalline to microcrystalline matrix (micritic to microsparitic cement) (Fig. 6b).

\subsubsection{Dissolutions}

This processes is a widespread phenomenon in the most studied carbonate samples where some or all parts of allochems are leached. In this case the bioclastics have been depleted or dissolved then filled by microspar or sparite cement. Most of the studied rock units show vuggy and cavernous textures which may be formed by dissolution processes (Figs. 6c and 6d).
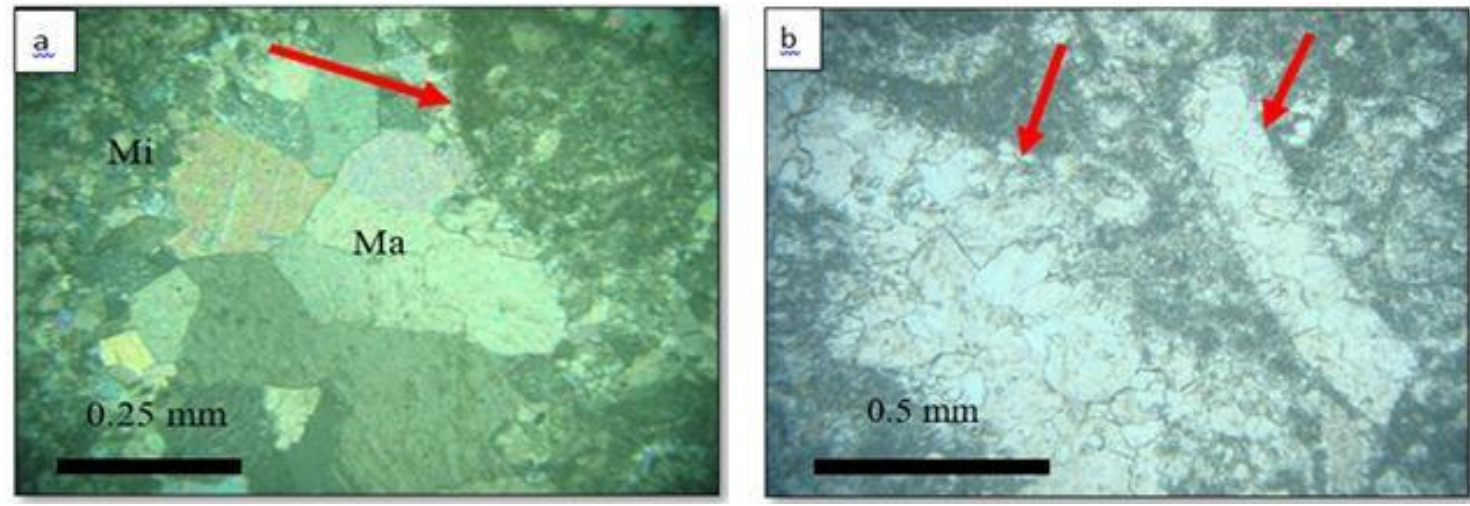

Fig5. Photomicrograph showing; (a) the micrite in the walls of bioclastics (arrow) had transported into microcrystalline "Mi" and crystalline spary calcite "Ma" within carbonate rocks of Sannur Formation, and (b) recrystallization from micrite to sparry calcite (neomorphism) (arrows)

International Journal of Mining Science (IJMS)

Page 9 


\section{MineralogY}

The mineral composition of the studied rock units was determined by using X-ray diffraction (XRD) patterns. The petrographical studies and X-ray diffraction analyses exhibit that the mineralogical composition of Middle Eocene is mainly carbonate minerals. Three samples were selected from the lithostratigraphic section and studied using X-Ray diffraction (XRD) analysis in the Lab of El-Tabbin Institute for Metallurgical Researches, Egypt. The analysis revealed that calcite and dolomite are the dominant carbonate minerals forming the rock units covering W. Mawathil area (Fig. 7).
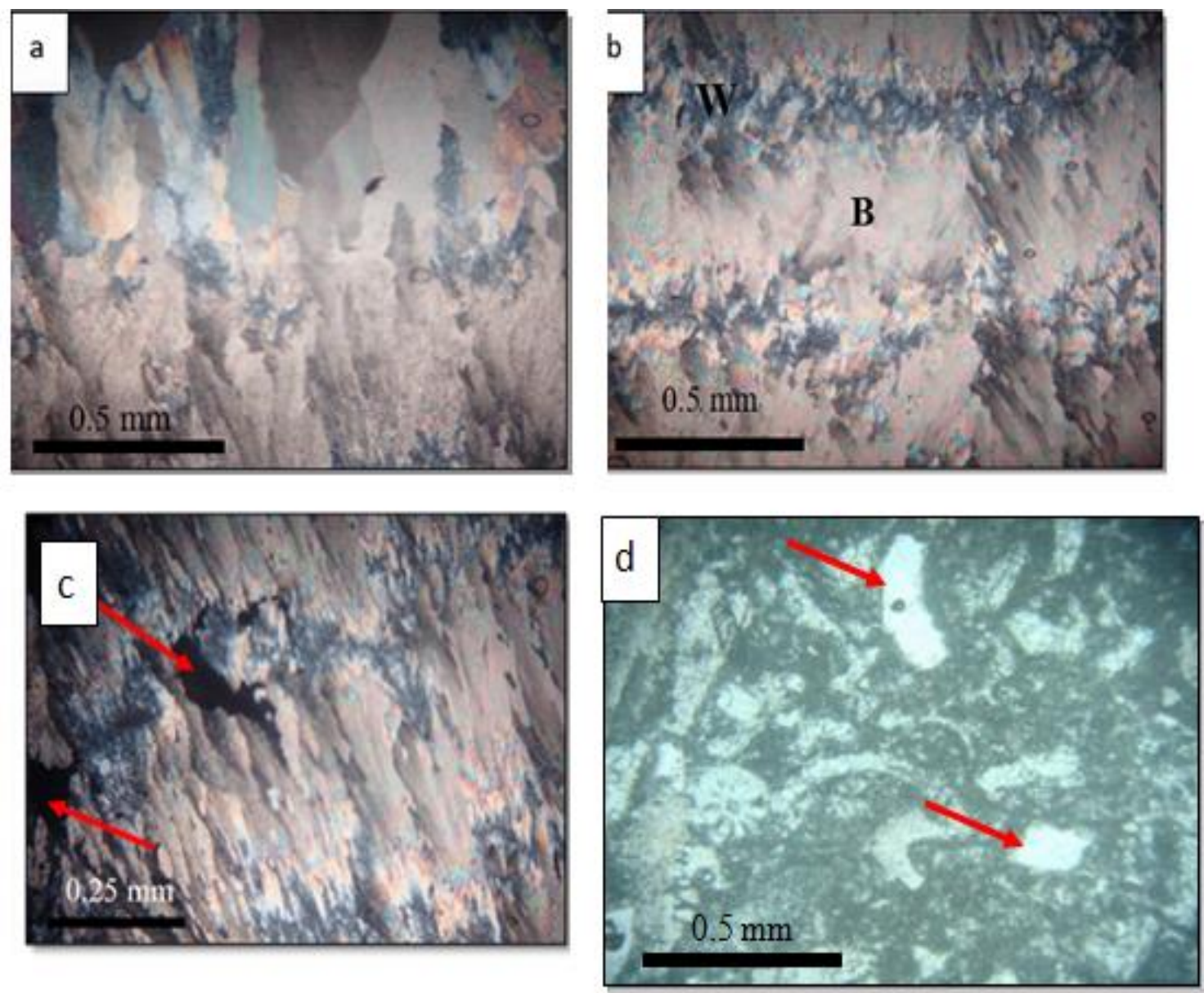

Fig6. Photomicrograph showing; (a) fibrous radial calcite cement of alabaster, and (b) gradualgrowth of alabaster bands; fine crystals of white bands " $W$ " alternating with coarse crystals of brownish translucent bands " $B$, (c) vuggy and cavernous texture (arrows) within the alabaster rocks due to the dissolution processes, and $(d)$ vuggy texture within the bucchino rocks (arrows)

\subsection{Carbonate Minerals}

\subsubsection{Calcite}

Calcite is a carbonate mineral consists of calcium carbonate. X-ray diffraction analysis of the studied rock samples showed that it is mainly calcite mineral. Calcite mineral is the main mineral in the Sannur Formation (Fig. 7).

\subsubsection{Dolomite}

Dolomite mineral refers to an anhydrous carbonate minerals which composed of calcium magnesium carbonate. The recorded dolomite in some studied limestone samples perhaps due to magnesium released by breakdown of metastable high magnesium calcite (Pettijohn, 1975). X-ray diffraction recorded the dolomite mineral which is characterized by the isolated rhombs shape (Fig. 7a). 

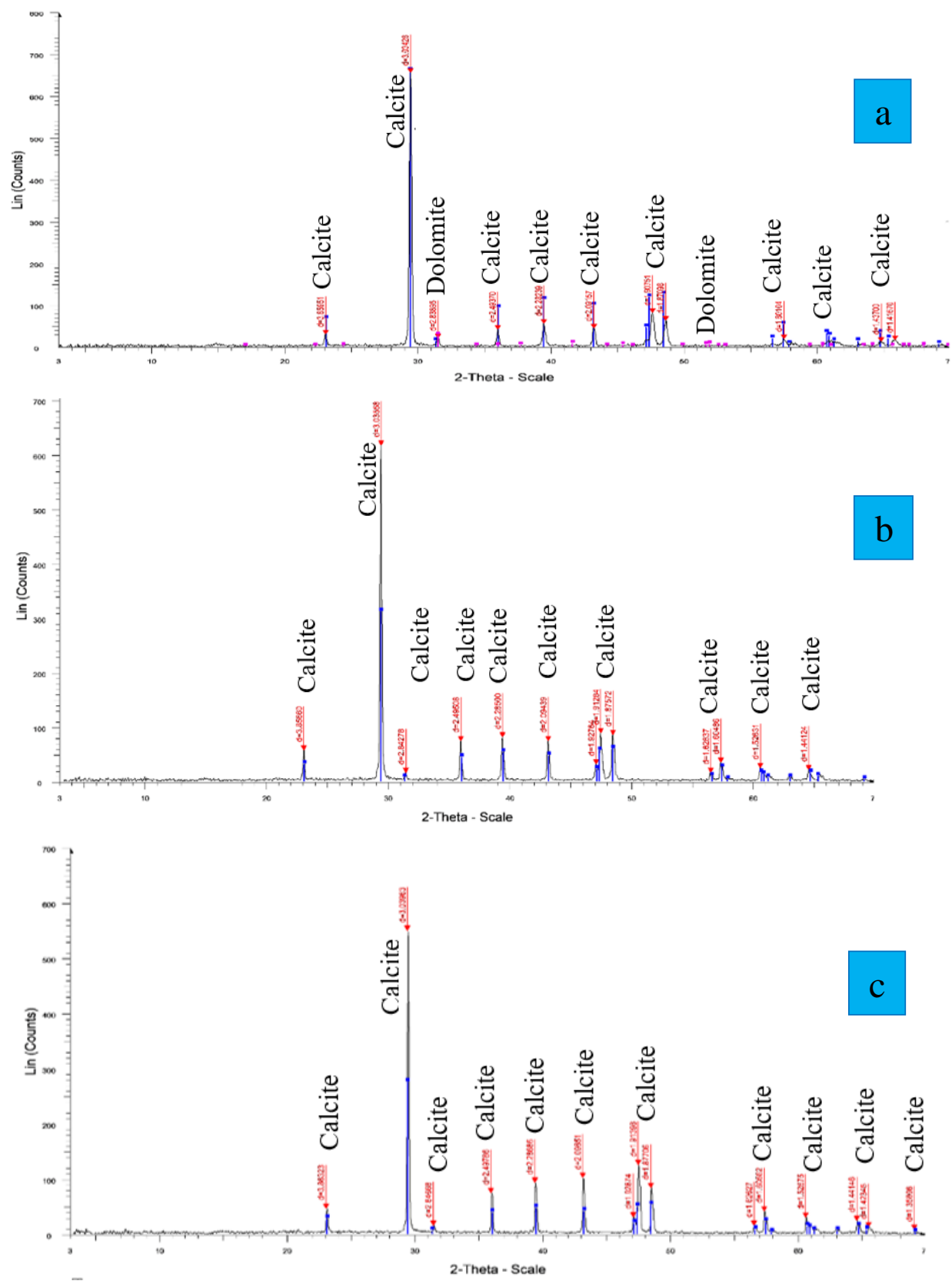

Fig7. Photpgraph showing X-Ray diffraction pattern; (a) alabaster rock, (b) bucchino rock, and (c) Chalky limestone

\subsection{Non- Carbonate Minerals}

Depending on microscopic investigations, the non-carbonates are represented by quartz, iron oxides and glauconite which occur as minor outcrops.

\subsubsection{Quartz}

Quartz is considered as a minor component in Middle Eocene carbonate rocks. Quartz grains were determined by using polarizing microscope as angular to sub-angular fine to coarse moderately sorted quartz grains. The microscopic investigation of the rock samples shows that the quartz is less abundant in carbonate rocks, but abundant in the terra rosa of the Sannur Formation (Fig. 4h). "Terra Rosa" is a term refer to the iron oxides and other elements distributed within alabaster body during the dissolution of limestone.

\subsubsection{Iron Oxide}

Iron oxide is recorded in the studied thin sections scattered as patches occasionally cementing the carbonate grains (Fig. 4h). 


\subsubsection{Glauconite}

Glauconite can be noticed as the main constituent mineral of the studied thin sections. It is also recorded in terra rosa, and present as rounded, homogeneous, pale green to yellowish green grains, forming macrocrystalline material. (Fig. 4h).

\section{SCANNING ELECTRON MICROSCOPE STUDY (SEM ANALYSIS)}

Scanning Electron Microscope study was carried out using JSM-6510LA Scanning Electron Microscope (JEOL, Japan) to identify the morphology of surface textures and microstructures of the rock samples.SEM analysis was carried out for three different rocks; alabaster, bucchino and chalky limestone to give us and confirm the results which obtained by the previous analysis. Also, the SEM study was done to identify the surface texture of the mineralogical composition of the Egyptian alabaster.

\subsection{SEM study of the Egyptian Alabaster}

SEM study of alabaster samples reveals that the major mineral component of the studied rock samples is calcite. The SEM analysis clearly shows that the shape of calcite crystals is rhombic form (Fig. 8a). Very fine scattered calcite crystals were observed reflecting different generations of calcite crystallization (Fig. 8b) indicating that the limestone were subjected to secondary processes after deposition. It shows also the presence of small vugs (Fig. 8c) and cleavage structures (Fig. 8d). SEM study show the difference between the bands of alabaster rocks. The crystal shape of milky white band is microcrystalline (Fig. 8e), may be due to the rapid deposition of the carbonated water (Blasy, 2014). On the other hand, the brownish-translucent band is macrocrystalline, this indicates a slow rate of crystallization (Fig. 8f).

\subsection{SEM Study of the Bucchino Rock}

Bucchino rocks are accompanying Egyptian alabaster at W. Mawathil area. The SEM showed that the morphology of textures of the bucchino rocks are different from alabaster. It showed that most of calcite crystals are of irregular form and associated with another crystals. The surface textures of the studied samples containing more vugs than those found in alabaster rock (Fig. 9a). The surface textures of studied bucchino samples are characterized by a laminate fabric (Fig. 9b).
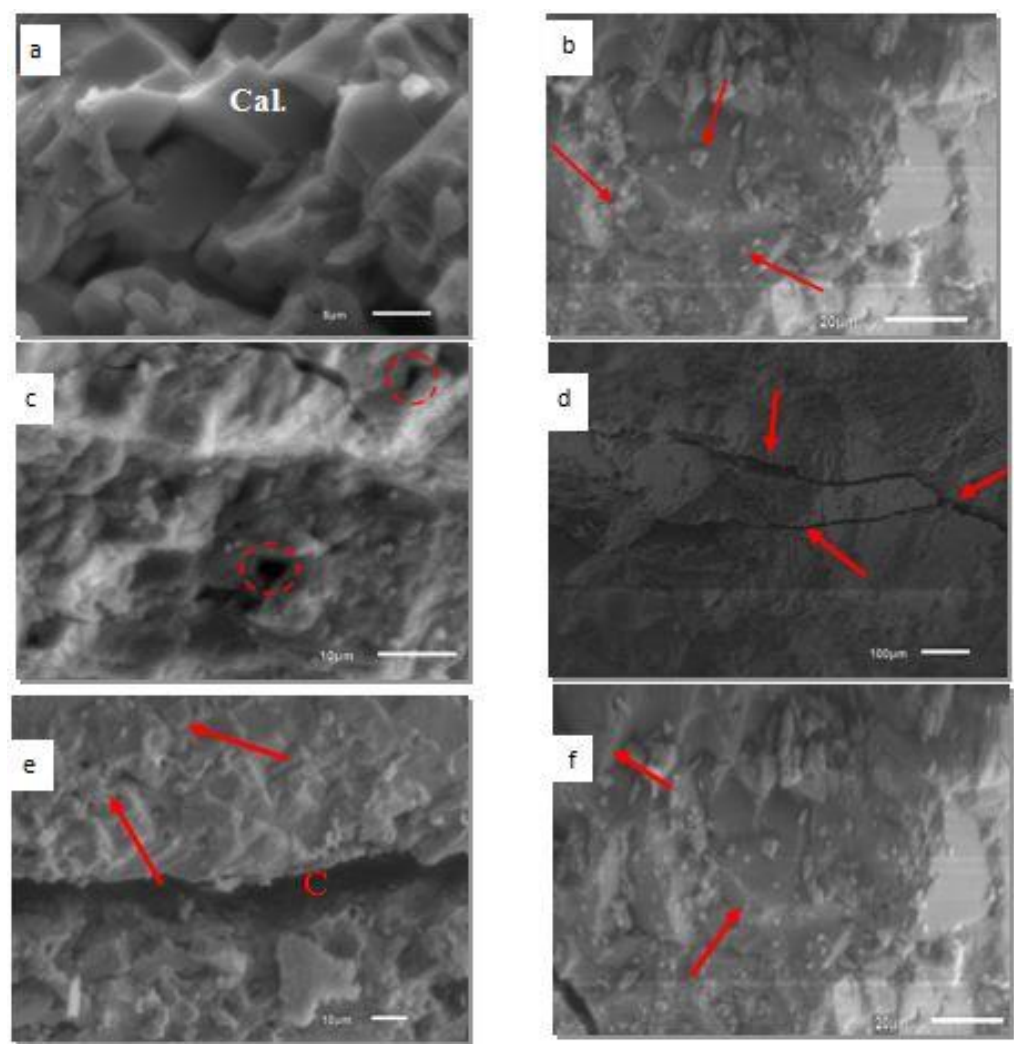

Fig8. SEM micrograph shows; (a) the morphology of the calcite rhomb "cal." of the alabaster rock of $W$. Mawathil, (b) very fine scattered calcite crystals of alabaster rock (arrows), (c) the alabaster containing small vugs (circles), (d) the alabaster containing cleavage structures (arrows), (e) microcrystalline of milky white band of "Egyptian alabaster" (microcrystalline calcite) (arrows) including cleavage " $C$ ", and (f) macrocrystalline calcite of brownish-translucent band of "Egyptian alabaster" (arrows) 

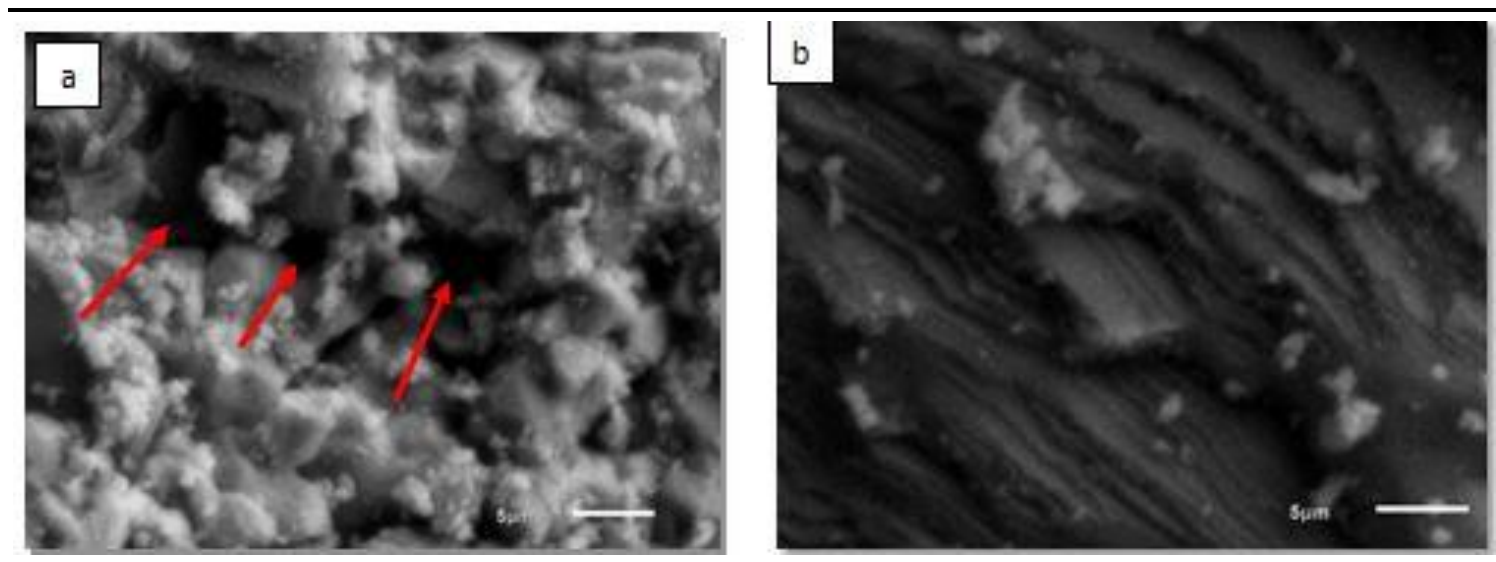

Fig9. SEM micrograph shows; (a) the surface topography and composition of the bucchino samples, including more vugs (arrows), and (b)SEM micrograph shows a laminate fabric in the bucchino samples of Sannur Formation at W. Mawathil area

\subsection{SEM Study of the Limestone Rock}

Scanning Electron Microscope study of the limestone showed that the calcite crystals of limestone are large and well defined. The calcite crystals appear as rhombs (Fig. 10a). It showed that the limestone is more porous where the interspaces between the crystals are larger than those found in both the bucchino and alabaster rocks (Fig. 10b).
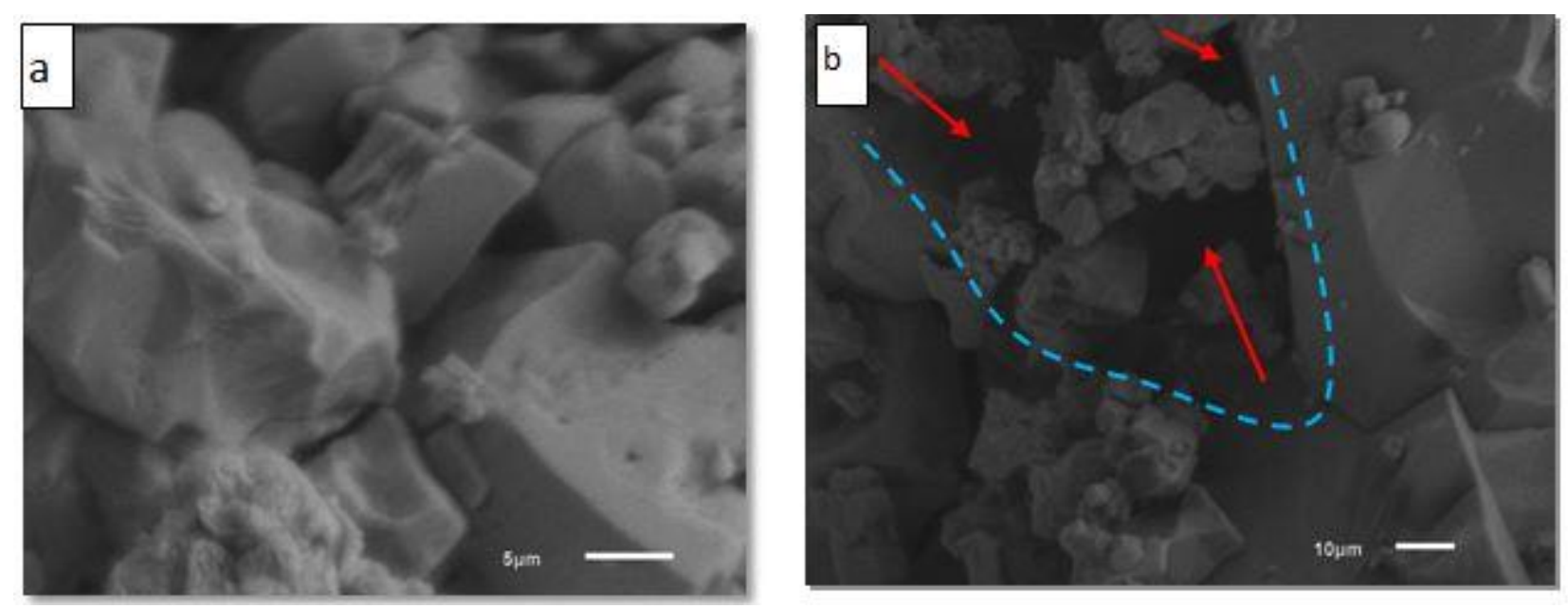

Fig10. SEM micrograph shows; (a) the surface textures of limestone of Sannur Formation at W. Mawathil area, and (b) microcrystalline, macrocrystalline calcite, and very large vug (arrows) in limestone rock.

\section{CONCLuSIONS}

Most of Middle Eocene rocks in the study area are mainly fossiliferous limestone that associated with patches of crystalline calcite (alabaster). Six microfacies types are recognized in these carbonate rocks, these are: Echinoidal bioclastic wackestone, Molluscan bioclasic packstone, Foraminiferal bioclasic packstone, Nummulitic bioclastic packstone, Foraminiferal packstone, and Sandy molluscan grainstone. The diagenesis of carbonaterocks involves several processes occurred in near surface marine and meteoric environments. The porosity and permeability are also affected by a diageneses. The petrographical investigation of the studied carbonate rocks revealed some processes such as neomorphism (recrystallization), cementation and dissolutions. These processes that act on these materials after deposition causing influence by physicochemical processes on the studied rocks.Mineralogical studiesusing X-ray diffraction (XRD) analyses exhibit that the main mineral composition of the Middle Eocene rocks are carbonate minerals usually calcite with some dolomites. On the other hand, The SEM analysis of alabaster rocks show that calcite is in association with vugs and cleavage structure. It gives also a prediction of the rate of crystallization of the alabaster bands and showed the difference between them; the shape of milky-white band is fine-grained, indicating that the calcium carbonate had been rapidly precipitated as calcite mineral when $\mathrm{CO}_{2}$ is given off, while the grain shape of the brownish-translucent band is coarse, this indicates a slow rate of crystallization. 


\section{REFERENCES}

Akaad, M.K. and Naggar, M.H., 1963. Geology of the Wadi Sannur alabaster and the general geologic history of the Egyptian alabaster deposits. Bulletin of Institute Desert, Egypt, 3, 34-57.

Akaad, M.K. and Naggar, M.H., 1965. Petrography of Wadi Sannur alabaster and its bearing on the mode of formation of Egyptian alabaster. Bulletin of the Egyptian Geographical Society, Egypt. 37, 35-46.

Alamoudi, Z. M., and El-Taher, A., 2016. Application of Nuclear Analytical Techniques in Elemental Characterization of Wadi El-Nakhil Alabaster, Central Eastern Desert, Egypt. Science and Technology of Nuclear Installations, 92-96.

Blasy, M., 2014. Thermal characterization and mineral composition of the Egyptian alabaster "carbonate rocks". International Journal of Science and Research, 3, 1196-1199.

Boukhary, M.A., and Abdelmalik, W.M., 1983. Revision of the stratigraphy of the Eocene deposits in Egypt. Neues Jahrbuch für Geologie und Paläontologie. 6, 321-337.

Craig, J.R., and Vaughan, D.J., 1981. Ore Microscopy and Ore Petrography, A Wiley Interscience Publication, New York, NY, USA.

Dunham, R.J., 1962. Classification of carbonate rocks according to depositional texture. In: Classification of Carbonate Rocks (Ham, W.E., ed.), Tulsa, Okla, American Association of Petroleum Geologists, 1, p. 108-121.

Flügel, E., 2004. "Microfacies data: matrix and grains." Microfacies of Carbonate Rocks. Springer, Berlin, Heidelberg, p. 73-176.

Folk, R.L., 1959. Practical petrographic classification of limestone. Bulletin of Canadian Petroleum Geology, $43,1-38$.

Folk, R.L., 1962. Spectral Subdivision of Limestone Types. 62-84 p.

Folk, R.L., 1965. Some aspects of recrystallization in ancient limestone; Dolomitization and Limestone Diagenesis. Society of Economic Paleontologists Mineral. (SEPM). 14-48 p.

Folk, R.L., 1974. The natural history of crystalline calcium carbonate; effect of magnesium content and salinity. Journal of Sedimentary Research. 44, 40-53.

Gharieb, S.E., 1998. Geological studies on the Eocene rocks and associated karst features and facies in the East Beni-Suef area, North Eastern Desert, Egypt. Ph. D. Thesis, Faculty of Scince, Cairo University, Giza, Egypt, 74-79 p.

Klemm and Klemm, 2001. The building stones of ancient Egypt - a gift of its geology. Journal of African Earth Sciences. 33, 631-642.

Pettijohn F.J., 1975. Sedimentary Rocks. $2^{\text {nd }}$ Edition, Harper and Row Publishers, New York.

Railsback, B.L., Dabous, A.A., Osmond, J.K, and Fleisher, C.J., 2002. Petrographic and geochemical screening of speleothems for U-series dating: An example from recrystallized speleothems from Wadi Sannur Cavern, Egypt. Journal of Cave and Karst Studies 64, 108-116.

Rifai, R.L., 2007. Reconstruction if the Middle Pleistocene climate of South Mediterranean using the Wadi Sannur Speleothem, Eastern Desert, Egypt; Carbonates and Evaporites, 22, 73-85.

Tucker, M.E., 2001. Sedimentary petrology: An Introduction to the Origin of Sedimentary Rocks, text book, $3^{\text {rd }}$ edition, $129 \mathrm{p}$

Yahia, A., 2010. Geomorphological and sedimentological studies on the upper tributaries of Wadi and Gabal Sannur, South East Beni-Suef, Egypt. M. Sc., Thesis, Geology Department. El-Minia University, ElMinia, Egypt.

Citation: Darweesh M. El-Kholy, (2020)" Petrography and Mineralogy of Egyptian Alabaster in Wadi Mawathil Area, Eastern Desert, Egypt", International Journal of Mining Science (IJMS), 6(3), pp. 4-14. DOI: http://doi.org/10.20431/2454-9460.0603002

Copyright: () 2020 Darweesh M. El-Kholy, This is an open-access article distributed under the terms of the Creative Commons Attribution License, which permits unrestricted use, distribution, and reproduction in any medium, provided the original author and source are credited. 